\title{
FORMATION OF THE READINESS OF FUTURE TEACHERS OF PHYSICAL CULTURE FOR PROFESSIONAL ACTIVITY
}

\author{
Yurii Kurnyshev ${ }^{1}$, Taras Palagniuk ${ }^{2}$, Olena Hauriak ${ }^{3}$, Mykola Osadets ${ }^{4}$
}

$1 \mathrm{PhD}$ in Pedagogy, lecturer Department of Physical Culture and Foundations of Health, Yuriy Fedkovich Chernivtsi National University,

http://orcid.org/0000-0002-5468-7974

e-mail:kurnyshev@ukr.net

$2 \mathrm{PhD}$ in Pedagogy, Associate Professor Head of the Department of Physical Education, Yuriy Fedkovich Chernivtsi National University, http://orcid.org/0000-0002-6379-1933

e-mail: t.palagniuk@chnu.edu.ua

$3 \mathrm{PhD}$ in Pedagogy, lecturer Department of Physical Culture and Foundations of Health, Yuriy Fedkovich Chernivtsi National University,

http://orcid.org/0000-0002-2354-7012

e-mail: olena.hauriak@gmail.com

4 Professor of the Department of Physical Education, Yuriy Fedkovich Chernivtsi National University, https://orcid.org/0000-0003-2343-2220

e-mail:m.osadets@chnu.edu.ua

\begin{abstract}
The theoretical study reveals professional training as a dynamic process in which the goals of education and the formation of competencies, application of the received social experience are realized. In this aspect, education involves the creation of a holistic system of lifelong learning, development and upbringing of a person that provides training in various spheres of educational activity in accordance with the educational needs of the subjects of the pedagogical process.

The training of the specialist, in particular a teacher, has its own peculiarities depending on the chosen specialty. Therefore, it is appropriate to consider the peculiarities of the preparation of the future teacher of physical culture at the pedagogical institution of higher education.

The contents of the preparation of the teacher of physical culture for professional activity in a comprehensive educational institution, that is, the implementation of the holistic pedagogical process of upbringing the physical culture of the person, is based on the expanded interpretation of the content of pedagogical education.

In the structure of readiness for the professional activity of the future teacher of physical education, we distinguish the motivational, theoretical and practical-creative components, each of which has specific target functions and in this sense relatively independent. This structure of the components of professional preparedness provides its containing basis, which determines the possibility of implementing various types of vocational and pedagogical activities in full.

The problem of substantiating the essential characteristics of the readiness of the teacher of physical culture for professional activity in the theory of special pedagogical education is not new, but there is no a single interpretation of it, and in many cases - it is identified with other categories. This identification expresses the totality of professionally determined requirements to work and the teacher's personality, namely: preparedness, competence, qualification, mastery, artfulness, professionalism.

The practical significance of the received results of the study is determined by the fact that its theoretical positions and conclusions create real prerequisites for the scientific provision of the training of the future teacher of physical culture and the implementation of a holistic pedagogical process of promoting the physical culture of the students' personality.
\end{abstract}

Keywords: readiness for professional activity, components, future teacher of physical culture, personality. 
Introduction. The problem of substantiating the essential characteristics of the readiness of the teacher of physical culture for professional activity in the theory of special pedagogical education is not new, but there is not a single interpretation of it, and in many cases it is identified with some other categories.

Materials. The analysis of works devoted to the problem of training pedagogical staff at institutions of higher education, indicates the complexity of the concept of "training', the breadth and variety of its interpretations. For example, M. Skatkin (1986), V. Shadrikov (1996) and others determine the training as a process that realizes the goals of education and the formation of competencies, the application of the received social experience. In this aspect, education foresees the creation of a holistic system of lifelong learning, development and upbringing of the person, which provides training in various spheres of educational activities in accordance with the educational needs of subjects of the pedagogical process. M. Vilenskiy and R. Safin define professional training of the specialist as a set of general scientific and special knowledge and skills requirements for physical and mental, moral and personal qualities, development of pedagogical skills, possessed by which the specialist can successfully carry out his professional responsibilities (Vilenskiy and Safin, 1989) .

Summarizing the findings of scientists, it can be argued that the professional and pedagogical orientation of the future teacher of physical culture is an integral dynamic personality property, expressing the dominant conscious and unconscious attitudes (towards the teaching profession), which predetermine the preparation for the future activity and the success of its implementation.

The aim of the paper is to substantiate the features of training of future teachers of physical culture for professional activity.

Methods: theoretical analysis and generalization of data of scientific-methodical and special literature, study of documentary materials; observation; questionnaire.

Results and discussions. Scientific novelty of research results is in specification of indicators of the formation of readiness of future teachers of physical culture: motivational (valuable attitude, professionalcognitive interest in mastering the profession, motivational achievement).

The practical significance of the results of the study is determined by the fact that its theoretical provisions and conclusions create real prerequisites for the scientific support of training the future teacher of physical culture and the implementation of the holistic pedagogical process of promoting the physical culture of the personality of students. So, the readiness of the teacher of physical culture for professional activity, that is, the implementation of the holistic pedagogical process of promoting the physical culture of the personality of students, is disclosed as a complex qualitative, structural and dynamic unity characterized by a certain level of special theoretical, practical, motivational values acquired as a result of upbringing, education, integrated into the teacher's creative pedagogical activity. The central core of the readiness of the teacher of physical culture for professional activity is positive directives, motivation and mastered of values of physical culture and the teaching profession. The indicated readiness includes professionally important traits of character, pedagogical abilities, a set of professional-pedagogical knowledge, skills and a certain experience of their application in practice.

The term "training" is understood as a dynamic process, the ultimate goal of which is the formation of such professional qualities as "readiness". In other words, preparation for the profession is nothing more than the formation of readiness for it.

The problem of substantiation of the essential characteristics of the readiness of the teacher of physical culture for professional activity in the theory of special pedagogical education is not new, but there is not a single interpretation of it, and in many cases, it is identified with other categories, expressing the totality of the professionally conditioned requirements for the work and personality of the teacher, namely: preparedness, competence, qualification, mastery, artfulness, professionalism.

The term "readiness" reflects the quality of integrity, integral efficiency, solves the problem of fixing unity in the variety of (close-to-content, but multi-dimensional) concepts. Considering the readiness as the product of activity which is characterized by objectivity (at what it is directed), aspectality (a set of components and their properties), integrity, representativeness (representation of adequate specialties) and a measure, we reveal a series of relations between the marked characteristics of the same concepts, namely: readiness integrity; professionalism - objectivity; competence and competence aspectality; qualification representativeness; mastery measure.

Pedagogical studies of human readiness for professional activity are addressed, mainly, to its various aspects and on the basis of the holistic pedagogical process, taking into account its regularities, driving forces and contradictions. There is a tendency to consider the definition of "professional readiness" as a complicated complex formation of personality in three conditionally fixed aspects component, complex, integrated. Component aspect is associated with the study of separate components of professional readiness; complex one involves 
consideration of the relations between separate components and their need in professional activity and in process of preparation for it; integrated one is connected with the study of all components, connections and relationships between them within a systematic approach to cognize essence of objects and phenomena.

G. Kodzhaspirova (2003) examines readiness as a complex personality formation, multifaceted and multilayered system of qualities, properties, which enable subject to carry out his professional activity more or less successfully. B. Slastonin (1976) considers readiness for pedagogical activity as a unity of various types of readiness. Under psychological readiness, he understands the effective state of personality, expressed in the ability for productive realization of the perceived knowledge, skills and abilities, activization of the activity and the possibility to make an independent decision of complex professional tasks, quick orientation, productively implementation of making decision, the creation of the creative atmosphere.

A characteristic feature of the teacher's work is that he deals with both the object of activity (educational material) and the subject (a separate student and a team of students). Hence, the dual orientation of his activity follows: on one hand, mastery of educational material makes the teacher know his subject deep and thoroughly and work out the material in such a way that it will be scientific, accessible and interesting for students; and on the other hand, the teacher must know the age features, interests, abilities of the students. Ephimenko (2003) examines readiness as an integral personal formation, which includes the availability of certain knowledge, skills, and also a complex of individual psychological personality traits that condition the high efficiency of professional functioning in any field of practical activity and scientific research work.

Consequently, the analysis of scientific literature makes it possible to highlight something general in the interpretation of the concept "readiness". First of all, this is a personal form of interpretation of the contents of education, which can be considered as a system of integrated properties, qualities and experience of the individual, having the properties of general theoretical and methodological readiness for pedagogical work.

\section{Motivational component of readiness.}

Motivational readiness component is the form of mental proactive state of the individual and complex quality of the personality, a system of integrative personality traits. And in the first and second cases motivational readiness is a regulator of pedagogical activity, a prerequisite for its effectiveness.

In psychology, it is the accumulated experience of the allocation of fundamental integrative (holistic) characteristics of the individual. Under the holistic property of the personality of the teacher of physical culture, we understand qualities and properties that contribute to the direction of the whole vital activity and impose their mark on many other qualities, subordinate them to their nature, integrate and unite them into a single whole.

The problem of identifying the integrative holistic property of the person in psychology has not got an unambiguous solution: B.Ananiev defines it as a "spiritual center", L.Bozhovich "orientation", V. Myasishchev "relation", D. Uznadze "setting", T. Shibutani "motivational core" and so on. However, researchers agree that all aspects of personality closely interact with each other, but the dominant influence still remains on its social side - worldview and direction, expressing needs, interests, ideals, aspirations, moral and aesthetic qualities of the personality.

It should be noted that the general orientation of the individual is closely linked with professional orientation of the personality of the teacher, understood as selective positive attitude towards the teaching profession (N. Levitov, V. Slastonin, A. Shcherbakov and others); system of motives of professional pedagogical activity (P. Shavir et al.); interest in the profession of the teacher and a tendency to engage in it (N. Kuzmin, A. Chornykh, etc.).

B. Slastonin (2000) considers the professional and pedagogical orientation of the teacher's personality to be a decisive feature of his professional competence: "The most active form of it is the propensity to act as a need for pedagogical activity, as a driving force in the development of pedagogical abilities, as one of the prerequisites for the achievement of pedagogical mastery".

Summarizing the findings of scientists, it can be argued that the professional-pedagogical orientation of the future teacher of physical culture is an integral dynamic personality characteristic, expressing the dominant conscious and unconscious attitudes (towards the pedagogical profession), which predetermine preparation for future activity and the success of its implementation.

Theoretical component of readiness.

The theoretical component of readiness of the future teacher of physical culture for professional activity includes a system of knowledge (pedagogical, psychological, valeological, physiological, professional, etc.). The absorption of this knowledge is intended to equip the future teacher of physical culture with the correct methodological approach to recognize the pedagogical reality, use pedagogical technologies in the educational branch "Physical Culture", created on the basis of new pedagogical concepts. Naturally, the perfect possession of this 
method will require specific psychological and pedagogical knowledge about the separate aspects of pedagogical phenomena.

Pedagogical consciousness, being the higher level of activity of the professional pedagogue, reflects pedagogical reality in the form of sensual and rational (imaginary) images, thus envisaging practical actions and giving them a purposeful character. The content of pedagogical consciousness also determines the nature of the transformation of pedagogical reality into the internal plan, the form of representations, thoughts, ideas and other components of the spiritual order, which, in the end, are expressed in knowledge and beliefs.

Consequently, the above considered point of view on the problem of professional pedagogical consciousness reveals the conditionality of the dynamics of readiness of the teacher of physical culture for the implementation of the holistic pedagogical process of promoting the physical culture of the student's personality by the level of the formation of his pedagogical consciousness and the style of scientific and pedagogical thinking. Developed pedagogical thinking, providing a profound understanding of the contents of pedagogical information, perceives knowledge and ways of activity through the prism of own individual experience and helps to gain the personal meaning of professional activity.

\section{Practical-creative component of readiness.}

The teacher of physical culture must fully own practical actions, consisting of a number of techniques and operations aimed at creating the necessary conditions for realization of the educational work with students (division of responsibilities of team members, determination of job placement of students, the sequence of the activities of students, the creation of conditions for self-control and intercontrol, the order of change of activities or stages of the tasks implementation). The indicated practical actions are the basis of practical and creative readiness of the teacher of physical culture.

Naturally, there is a question about the quality of knowledge. If we consider the quality of knowledge as the reflection properties of things (processes, events), processed in terms of human experience, then, depending on what cognitive processes are involved in reflection, knowledge can be scientific and empirical. Scientific knowledge is reflected in terms during the direct participation of abstract thinking. Therefore, Abdullin's (1990) statement on the essence of pedagogical skills as a form of the functioning of theoretical knowledge seems to be substantiated. In pedagogical skills "first of all, psychological and pedagogical knowledge, as well as theoretical knowledge of special and social-political disciplines" are resulted. So, determining the great importance of systematic and purposeful work on the training of future teachers of physical culture with special psychological and pedagogical knowledge, as well as sports-pedagogical, scientific one (theories and methods of training of motor skills), it is necessary to form a relation to them as to the cornerstone necessary for the development of pedagogical skills.

The practical readiness of the teacher of physical culture is manifested through constructive, communicative, organizational, research skills that have their own specifics, mastery of which is a necessary prerequisite for the formation of the physical culture of students. Practical preparedness as motivational and theoretical one, must be permeated with pedagogical consciousness and feelings. Besides, it should be approximated to the level of creative and pedagogical activity and the teacher's readiness for productive pedagogical work, creativity.

The selected stages of professional development of the personality of the teacher as a carrier of physical culture can serve as the theoretical basis of constructing a system of formation of creative readiness.

The creative personality is characterized by such features as: readiness for risk, independence of judgments, impulsivity, criticality of judgments, identity, courage of imagination and thought.

Conclusions. Thus, motivational, theoretical and practical-creative preparedness creative and the creativity of the teacher of physical culture (in the structure of his professional readiness to implement the holistic pedagogical process of promoting the physical culture of the student personality) are closely interrelated and interconnected. Unity of relatively independent types of readiness of the teacher of physical culture and, therefore, the integrity of his personality, depend on the level of development of professional selfconsciousness.

Peculiarities of preparedness of the modern teacher of physical culture involve not only mastering the skills that are directly related to the educational process (constructive, communicative, organizational, research, etc.), but also the skills to perform the following professional activities, the importance of which has improved greatly for today, namely: a diagnostic activity, which aims at providing a systematic study of the level of the physical development of analysis of each individual student and on the basis of the received data to predict further physical improvement, foreseeing of anticipation of possible consequences; rehabilitation activities, oriented at the restoration (in the process of work or intensive lessons) of other activities of the physical, mental, intellectual properties of students; the 
development of methodological support and implementation of rehabilitation programs for students with poor health, therapeutic use of physical exercises to restore the damaged subsystems of the student's body; reproductive activity, which involves the creation of a social and cultural environment at the educational institution aimed at cultivating physical culture and sports among all subjects of the pedagogical process (students and their parents, teachers and other teachers) at the educational institution; sports activity that provides for the disclosure of the maximum possibilities of students, potential reserves, satisfaction of the need for competitive activity, the achievement of certain sports heights; educational - propaganda activity, including educational activity aimed at the assimilation of social and historical experience of mankind in the branch of fundamental theory and education about physical and human development, security of formation of rational separate fund of motor skills needed in life, and the educational activity, which is in the use of special physical exercises to form a physically, mentally and socially mature person; preventive activity (or activity of the formation of a healthy lifestyle), which is associated with security of the optimal development of human-specific physical qualities, and on their basis-improvement of physical development, and strengthening of the health of students.

\section{List of references}

Абдуллина, О.А., 1990. Общепедагогическая подготовка учителя в системе высшего педагогического образования. М.: Просвещение, 1990.

Бабанский, Ю.К., 1973. Оптимизачия процесса обучения (аспект предупреждения неуспеваемости школьников): aвтореферат. Доктор наук. Ростовский-на-Дону государственный педагогический институт.

Виленский, М.Я. и Сафин, Р.С., 1989. Профессиональная направленность физического воспитания студентов педагогических спещиальностей. М.: Высшая школа.

Выдрин, В.М., Зыков, Б.К. и Лотоненко, А.В., 1991. Физическая культура студентов вузов: учебное пособие. Воронеж, Изд-во ВГУ.

Єфіменко, П.Б., 2003. Педагогічні умови забезпечення різнорівневої професійної підготовки майбутніх фахівиів фізичної культури: автореферат. Кандидат наук. Харківський державний педагогічний університет імені Г.С. Сковороди.

Коджаспирова, Г.М., 2003. Педагогика: учебник. М.: ВЛАДОС.

Сластенин, В.А. и Мищенко, А.И., 2000. Профессионально-педагогическая подготовка современного учителя. М.: Логос.

Скаткин, М.Н., 1986. Методология и методика педагогических исследований: (в помощь начинающему исследователю). М.: Педагогика.

Сластенин, В.А., 1976. Формирование личности учителя советской школы в процессе профессиональной подготовки. М.: Просвещение.

Фокин, Ю.Г., 2002. Преподавание и воспитание в высшей школе: Методология, иели и содержание, творчество. М.: Издательский центр "Академия".

Шадриков, В.Д., 1996. Психология деятельности и способности человека: учебное пособие. М.: Логос.

\section{Translated \& Transliterated}

Abdullina, O.A, 1990. Obschepedagogicheskaya podgotovka uchitelya v sisteme vyisshego pedagogicheskogo obrazovaniya [General pedagogical training of the teacher in the system of higher pedagogical education]. M.: Prosveschenie, 1990, [in Russian].

Babanskiy, Yu.K., 1973. Optimizatsiya protsessa obucheniya (aspect preduprezhdenii neuspevaemosti shkolnikov): avtoreferat [Optimization of the learning process (aspect of prevention of unsuccessfulness of schoolchildren: dissertation thesis) Doctor nauk. Rostovskiy-na-Donu gosudarstvennyiy pedagogicheskiy institut, [in Russian].

Vilenskiy, M.Ya. i Safin, R.S, 1989. Professionalnaya napravlennost fizicheskogo vospitaniya studentov pedagogicheskih spetsialnostey [Professional orientation of physical education of students of pedagogical specialties]. M.: Vyisshaya shkola, [in Russian].

Vyidrin, V.M, Zyikov, B.K i Lotonenko, A.V, 1991. Fizicheskaya kultura studentov vuzov: uchebnoe posobie [Physical culture of university students: manual]. Voronezh, Izd-vo VGU, [in Russian].

Yefimenko, P.B, 2003. Pedahohichni umovy zabezpechennia riznorivnevoi profesiinoi pidhotovky maibutnikh fakhivtsiv fizychnoi kultury: avtoreferat. Kandydat nauk [Pedagogical conditions of provision of various levels of professional training of future specialists in physical culture: dissertation thesis. PhD.]. Kharkivsky derzhavnyi pedahohichnyi universytet imeni HS Skovorody, [in Ukrainian].

Kodzhaspirova, G.M, 2003. Pedagogika: uchebnik [Pedagogy: a textbook]. M.: VLADOS, [in Russian].

Slastenin, V.A and Mischenko, AI, 2000. Professionalno-pedagogicheskaya podgotovka sovremennogo uchitelya [Professional and pedagogical training of the modern teacher]. M.: Logos, [in Russian].

Skatkin, M.N, 1986. Metodologiya i metodika pedagogicheskih issledovaniy: (v pomosch nachinayuschemu issledovatelyu) [Methodology and technology of pedagogical research: (for beginner researcher)]. M.: Pedagogy, [in Russian]. 
Slastenin, V.A, 1976. Formirovanie lichnosti uchitelya sovetskoy shkolyi v processes professionalnoy podgotovki [Formation of the personality of the teacher of the Soviet school in the process of professional training]. M.: Prosveschenie, [in Russian].

Fokin, Yu.G., 2002. Prepodavanie $i$ vospitanie v vyisshey shkole: Metodologiya, tseli i soderzhanie, tvorchestvo [Teaching and upbringing in higher education: Methodology, goals and content, creativity]. M.: Izdatelskiy center "Akademiya", [in Russian].

Shadrikov, V.D, 1996. Psihologiya deyatelnosti i sposobnosti cheloveka: uchebnoe posobie [Psychology of human activity and abilities: manual]. M.: Logos, [in Russian].

\section{Формування готовності майбутніх учителів фізичної культури до професійної діяльності}

\section{Юрій Курнишев ${ }^{1}$, Олена Мороз르 Олена Гауряк³, Микола Осадець ${ }^{4}$,}

1 кандидат педагогічних наук, викладач кафедри фізичної культури та основ здоров'я, Чернівецький національний університет імені Юрія Федьковича,

2 кандидат наук з фізичної культури і спорту, доцент кафедри фізичної культури та основ здоров'я, Чернівецький національний університет імені Юрія Федьковича,

3 кандидат педагогічних наук, викладач кафедри фізичної культури та основ здоров'я, Чернівецький національний університет імені Юрія Федьковича,

4 професор кафедри фізичного виховання, Чернівецький національний університет імені Юрія Федьковича,

Реферат. У теоретичному дослідженні розкрито професійну підготовку як динамічний процес, в якому реалізуються цілі освіти й формування компетенцій, застосування отриманого соціального досвіду. У цьому аспекті освіта передбачає створення цілісної системи безперервного навчання, розвитку й виховання людини, що забезпечує підготовку в різних сферах навчальної діяльності відповідно до освітніх потреб суб'єктів педагогічного процесу.

У структурі готовності майбутнього вчителя фізичної культури до професійної діяльності виділяємо мотиваційний, теоретичний та практично-творчий компоненти, кожен з яких має специфічні цільові функції. Цей склад компонентів професійної готовності забезпечує ії змістову базу, що визначає можливість здійснення різних видів професійно-педагогічної діяльності в повному обсязі.

Проблема обгрунтування істотних характеристик готовності вчителя фізичної культури до професійної діяльності в теорії спеціальної педагогічної освіти не нова, проте відсутнє єдине ії тлумачення, а в багатьох випадках - у iіï ототожненні з іншими категоріями, що виражає сукупність професійно-зумовлених вимог до праці й особистості вчителя, а саме: підготовленість, компетентність, кваліфікація, майстерність, умілість, професіоналізм.

Практичне значення одержаних результатів дослідження визначається тим, що його теоретичні положення i висновки створюють реальні передумови для наукового забезпечення підготовки майбутнього вчителя фізичної культури до реалізації цілісного педагогічного процесу виховання фізичної культури особистості учнів.

Ключові слова: готовність до професійної діяльності, компоненти, майбутній вчитель фізичної культури, особистість. 